\title{
Human platelet nitric oxide synthase activity: an optimized method
}

\author{
Elisa Mitiko Kawamato', Isaias Glezer ${ }^{1}$, Carolina Demarchi Munhoz ${ }^{1}$, Cristiane Bernardes ${ }^{1}$, \\ Cristoforo Scavone ${ }^{1 *}$, Tania Marcourakis ${ }^{1,2}$
}

${ }^{1}$ Departamento de Farmacologia, Instituto de Ciências Biomédicas, ${ }^{2}$ Centro de Investigações em Neurologia, Hospital das Clínicas/FMUSP (LIM-15), Universidade de São Paulo

*Correspondence:

C. Scavone

Avenida Professor Lineu Prestes, 1524

Departamento de Farmacologia

Instituto de Ciências Biomédicas

Universidade de São Paulo

CEP 05508-900 - Cidade Universitária

São Paulo - Brazil

E-mail: cscavone@icb.usp.br
We investigated the kinetic analysis of human platelet Nitric Oxide Synthase (NOS) activity by the rate of conversion of [ $\left.{ }^{3} \mathrm{H}\right]$ arginine to $\left[{ }^{3} \mathrm{H}\right]$-citrulline in unstimulated fresh platelets. NOS activity was present in the membrane fraction and cytosol, and was $\mathrm{Ca}^{2+}$ - and calmodulin dependent which is a characteristic of endothelial NOS. NOS activity was also dependent of NADPH since the omission of this cofactor induced an important decrease $(85,2 \%)$ in the enzyme activity. The kinetic varied with protein and arginine concentration but optimum concentrations were found up to 60 minutes, and up to $80 \mu \mathrm{g}$ of protein at $120 \mathrm{nM}$ of arginine and $0.5 \mu \mathrm{Ci}$ of ${ }^{3} \mathrm{H}$-arginine. NOS activity in the absence of FAD (flavin adenine dinucleotide), FMN (flavin mononucleotide) and $\mathrm{BH}_{4}$ (tetrahydrobiopterin) was only 2.8\% of the activity measured in the presence of these three cofactors. The enzyme activity was completely inhibited by L-NAME (1 mM) (98.1\%) and EGTA (5 mM) (98.8\%). Trifluoperazine (TFP) caused $73.2 \%$ inhibition of the enzyme activity at $200 \mu \mathrm{M}$ and $83.8 \%$ at $500 \mu M$. Under basal conditions, NOS Km for L-arginine was $0.84 \pm 0.08 \mu M$ and mean Vmax values were $0.122 \pm$ $0.025 \mathrm{pmol} . \mathrm{mg}^{-1} \cdot \mathrm{min}^{-1}$. Mean human NOS platelet activity was 0.020 $\pm 0.010 \mathrm{pmol} . \mathrm{mg}^{-1} . \mathrm{min}^{-1}$. Results indicate that the eNOS in human platelet can be evaluated by conversion of $\left[{ }^{3} \mathrm{H}\right]$-arginine to $\left[{ }^{3} \mathrm{H}\right]-$ citrulline in an optimized method, which provide reproducible and accurate results with good sensitivity to clinical experiments involving neurological and psychiatric diseases.

\section{INTRODUCTION}

Platelets, skin fibroblasts, lymphocytes, plasma and cerebrospinal fluid were identified in the search for peripheral tissues or body fluids suitable for exploring pathophysiology of neurodegenerative diseases such as Alzheimer's disease and psychiatric disorders, as depression, bipolar disorder and panic disorder (Gasparini et al., 1998). Platelets have been an important tool in neuropsychiatry and in psychopharmacology research since 
1955 (Pletscher, et al., 1956). A variety of biochemical perspectives is offered by platelets since they can synthesize a vast number of compounds, such as second messengers, have metabolizing enzymes (MAO), express different kinds of receptors, including adrenoceptors $\left(\alpha_{2}\right.$ and $\left.\beta_{2}\right)$, serotonin (5- $\left.\mathrm{HT}_{2}\right)$ and benzodiazepine receptors (Pletscher, 1988, Camacho, Dimsdale, 2000). Moreover, platelets share some similarities with neurons mainly in respect to the uptake system of serotonin (Pletscher, 1988). In addition, platelets can be used as model for the study of stimulus-response coupling mechanism since they yield homogeneous cell suspension that respond reliably and quantifiably to many pharmacological agonists (Hourani, Cusack, 1991).

The involvement of free radical in neurodegeneration is well established and the use of platelets to assess the role of these agents is of great interest. Peroxynitrite is formed from the interaction between nitric oxide (NO) and superoxide anions. Interestingly, NO has been suggested to protect against superoxide anionmediated injury under certain conditions (Miles et al., 1996). NO is an important physiological messenger with several biological functions such as regulation of vascular tone, blood pressure, vasodilation, sodium excretion, neurotransmission, macrophage cytotoxicity (Rees et al., 1989; Aisaka et al., 1989; Garthwaite, Boulton, 1995; Bredt, Snyder, 1990; Hibbs et al., 1990; Mckee et al., 1994). Moreover, NO also inhibits platelet aggregation through the activation of soluble guanylyl cyclase with the production of cGMP (Radomski et al., 1990a; Radomski et al., 1990b). NO synthase (NOS) is the enzyme responsible for the oxidation of L-arginine to generate $\mathrm{NO}$ and L-citrulline in a reaction that needs molecular oxygen, NADPH as a co-substrate and BH4, FAD, FMN and $\mathrm{Ca}^{2+}$ calmodulin as cofactors (Lincoln, Messersmith, 1995). In humans, three distinct forms of NOS have been identified. The neuronal NOS (nNOS) is found in neuronal and epithelial cells and acts in neurotransmission. The inducible NOS (iNOS) is found in macrophages and many other cells (such as glia) after stimulation by inflammatory signals such as cytokines or endotoxin. The endothelial NOS (eNOS) is found basically in endothelial cells. The activity of both eNOS and nNOS is $\mathrm{Ca}^{2+}$-calmodulindependent, whereas that of iNOS is $\mathrm{Ca}^{2+}$-insensitive (Bredt, Snyder, 1990; Mckee, et al., 1994).

Different methodological approaches have also been used to characterize NOS isoforms in platelets. Thus, studies using Western blots of cytosolic and membrane fractions of human platelets as well as sequential affinity chromatography were able to confirm the presence of a $\mathrm{Ca}^{2+} / \mathrm{CAM}$ dependent isoform similar to the eNOS (Sase, Michel, 1995; Muruganandam, Mutus, 1994). These results are also supported by spectroscopic determination (Radomski et al., 1990b), eletrochemical NO detection (Lantoine et al., 1995) and porphyrinic microsensor assay (Malinski et al., 1993), after platelet stimulation with collagen. In addition, there is evidence for an inducible isoform in human platelet NOS using reverse transcription polymerase chain reaction (Mehta et al., 1995; Berkels et al., 1997).

However, the problem among all these methods is the lack of sensitivity because of the small amount of NO production by platelets. Thus, the radiochemical assay based on the biochemical conversion of L-arginine with the production of stoechiometric quantities of L-citrulline and NO is considered as a simple, sensitive and specific method to measure the production of NO. When optimized, the conversion assay can provide reproducible and accurate results with good sensitivity.

We present here a method to the determination of NOS activity in human platelets by the conversion of tritium labeled L-arginine to tritium labeled L-citrulline. NOS activity was assessed under a variety of different conditions in order to optimize conditions for NOS activity in platelet homogenate to permit using small volume of whole blood and protein. Such information is important to validate NOS studies in human and rat platelet as well as in other peripheral tissues where eNOS has shown to act as an intracellular messenger. Furthermore, the optimized study will permit a simultaneous determination of the enzyme activity, cyclic GMP levels and cyclic GMP-dependent protein kinase activity in patients with several diseases.

\section{MATERIALS AND METHODS}

\section{Chemicals}

${ }^{3} \mathrm{H}$ - Arginine (specific activity $45.2 \mathrm{Ci} / \mathrm{mmol}$ ) was obtained from Dupont - New England Nuclear (Natick, MA) and scintillation cocktail was purchased from Ultima Gold ${ }^{\mathrm{TM}}$ (Packard BioScience BV, Groningen). ${ }^{3} \mathrm{H}-$ arginine from New England Nuclear is not $100 \%$ pure and decomposition or bacterial contamination can bring unspecific high radioactivity into the blank sample. Since the levels of radioactivity in the blanks largely determine the sensitivity of the assay, the ${ }^{3} \mathrm{H}$-arginine was purified before NOS assay in human platelets. This was performed by passing ${ }^{3} \mathrm{H}$-arginine through a Dowex ion-exchange column. The column was washed four times with $1 \mathrm{~mL}$ of distillated water, and the ${ }^{3} \mathrm{H}$-arginine was eluted with $0.02 \mathrm{M} \mathrm{NaOH}(2 \mathrm{~mL}) .{ }^{3} \mathrm{H}$-arginine was stored in aliquots sufficient for each assay run to prevent contamination of the stock. Dowex 50X8*-400, $\mathrm{H}^{+}$form, ion exchange resin 
was supplied by Sigma-Aldrich Chemicals (St. Louis, $\mathrm{MO})$. The resin was converted to the sodium form by washing in $1 \mathrm{~N} \mathrm{NaOH}$ for approximately five minutes and after in de-ionized water until $\mathrm{pH} 9-12$, followed by washing in HEPES buffer $(\mathrm{pH}=5,5)$ until $\mathrm{pH}<7$. HEPES, sucrose, EDTA, dithiothreitol, PMSF, leupeptin, pepstatin, calcium chloride, NADPH, calmodulin, FAD, FMN, $\mathrm{BH}_{4}$, L-NAME and arginine were obtained from Sigma-Aldrich Chemicals.

\section{Preparation of washed platelets}

The study was approved by the hospital's ethic committee and all subjects signed informed consent forms. Blood from normal healthy volunteers $(20 \mathrm{~mL})$, who were not taking any drug in the previous days, was drawn from an antecubital vein into citrate acid dextrose anticoagulant $(2.73 \%$ citric acid, $3.68 \%$ sodium citrate, $2 \%$ glucose). Platelet rich plasma was prepared within 30 min after blood collection by centrifuging the blood at 394 $\mathrm{x} g$. The plasma was then centrifuged at $1500 \mathrm{x}$ g to obtain the platelet pellet. The pellet was washed twice in Krebs buffer (pH 6) containing [mM] $140 \mathrm{NaCl}, 5 \mathrm{KCl}, 12$ sodium citrate, 10 glucose, 12.5 sucrose and centrifuged at $1500 \mathrm{x} \mathrm{g}$. All centrifugations were performed for $15 \mathrm{~min}$ at room temperature.

The platelets were ressuspended in a buffer ( $\mathrm{pH} 7.4)$ with $20 \mathrm{mM}$ HEPES, $0.32 \mathrm{mM}$ sucrose, $1 \mathrm{mM}$ dithiothreitol (DTT), $10 \mu \mathrm{g} / \mathrm{mL}$ leupeptin, $0.1 \mathrm{mM}$ EDTA, $1 \mathrm{mM}$ pepstatin, $1 \mathrm{mM}$ PMFS, and sonicated at $4{ }^{\circ} \mathrm{C}$. The sample was then treated with the ion-exchange resin (Dowex 50WX8-400, sodium form) to remove endogenous arginine. NOS activity was measured in the homogenate with an assay adapted from methods published previously (Bredt, Snyder, 1990; Mckee et al., 1994).

\section{Determination of Nitric Oxide Synthase Activity (NOS) in platelets}

The incubation medium $(\mathrm{pH}=7.4)$ contained $4 \mu \mathrm{M}$ FAD, $4 \mu \mathrm{M}$ FMN, $10 \mu \mathrm{g} / \mathrm{mL}$ calmodulin, $1.25 \mathrm{mM} \mathrm{Ca}^{2+}$, $1 \mathrm{mM}$ NADPH, $25 \mu \mathrm{M} \mathrm{BH}_{4}$ and one of the three different L-arginine concentrations $(10 \mu \mathrm{M}, 1 \mu \mathrm{M}, 120 \mathrm{nM})$. The reaction was started by adding the platelet samples in the desired protein concentration. Total platelet protein was determined in the homogenate using Biorad (Melville, NY) assay (Bradford, 1976).

After 30 and 60 minutes of incubation at $37^{\circ} \mathrm{C}$, the reaction was stopped by the addition of $1 \mathrm{~mL}$ of cold Hepes $20 \mathrm{mM}(\mathrm{pH}=5.5)$ and keeping the tubes in ice. ${ }^{3} \mathrm{H}$ - citrulline was separated from ${ }^{3} \mathrm{H}$-arginine through an ion exchange resin column (Dowex 50WX8-400, sodium form) and the addition of $1 \mathrm{~mL}$ of distilled water. Total eluate was collected in a scintillation vial containing $10 \mathrm{~mL}$ of Ultima Gold scintillation fluid. The radioactivity was determined in a Packard Liquid Scintillation Counter with $54 \%$ efficiency. Blanks consisted of homogenizing medium, without platelet samples, which was carried out through the identical process. All measurements were made in triplicate and corrected for the appropriate blanks. Total count refers to a vial containing $\left[{ }^{3} \mathrm{H}\right]$-arginine and Larginine without passing by the resin. The data were converted from cpm to $\mathrm{dpm}$ and specific activity (pmol. $\mathrm{mg}^{-1} \cdot \mathrm{min}^{-1}$ ) was calculated by using the following formula: [arginine] x [sample count]/[total count] x [protein] $\mathrm{x}$ time. Determination of $\mathrm{Km}$ and Vmax was done based on Lineweaver-Burk regression (Conrad, Davis, 1995).

\section{RESULTS}

\section{Linearity with time, protein and substrate concentration}

It might be assumed that NOS assay is highly dependent on the enzyme concentration and the incubation time. However, the activity of the enzyme can rapidly reach a plateau with time and with protein concentration. Thus, the first step was to determine the optimum conditions of time incubation and protein concentration to ensure that this plateau has not been reach as suggested by Hevel and Marletta (1994). For kinetic analysis of platelet NOS activity, it was necessary to carry out the NOS assay using different concentrations of the Larginine substrate. Therefore, three different L-arginine concentrations were tested: $10 \mu \mathrm{M}, 1 \mu \mathrm{M}, 120 \mathrm{nM}$ with a fixed concentration of ${ }^{3} \mathrm{H}$-arginine $(0.5 \mu \mathrm{Ci})$ (Figure 1$)$. The increase of ${ }^{3} \mathrm{H}$-arginine concentration was not useful as NOS activity did not increase with higher concentrations of that (data not shown). Preliminary experiments demonstrated that under standard conditions the assay was linear when protein concentration was up to $80 \mu \mathrm{g}$ and the time of reaction was up to 60 minutes at $120 \mathrm{nM}$ of arginine (Figure 1). Under basal conditions, NOS Km for L-arginine was $0.84 \pm 0.08 \mathrm{mM}$ and mean Vmax values were $0.122 \pm 0.025 \mathrm{pmol} . \mathrm{mg}^{-1} \cdot \mathrm{min}^{-1}$. Mean human NOS platelet activity was $0.020 \pm 0.010 \mathrm{pmol} \cdot \mathrm{mg}^{-1} \cdot \mathrm{min}^{-1}$.

\section{Cofactor requirement of platelet NOS activity}

Figure 2 shows the dependence of cofactor on platelet NOS activity. Almost no platelet NOS activity 


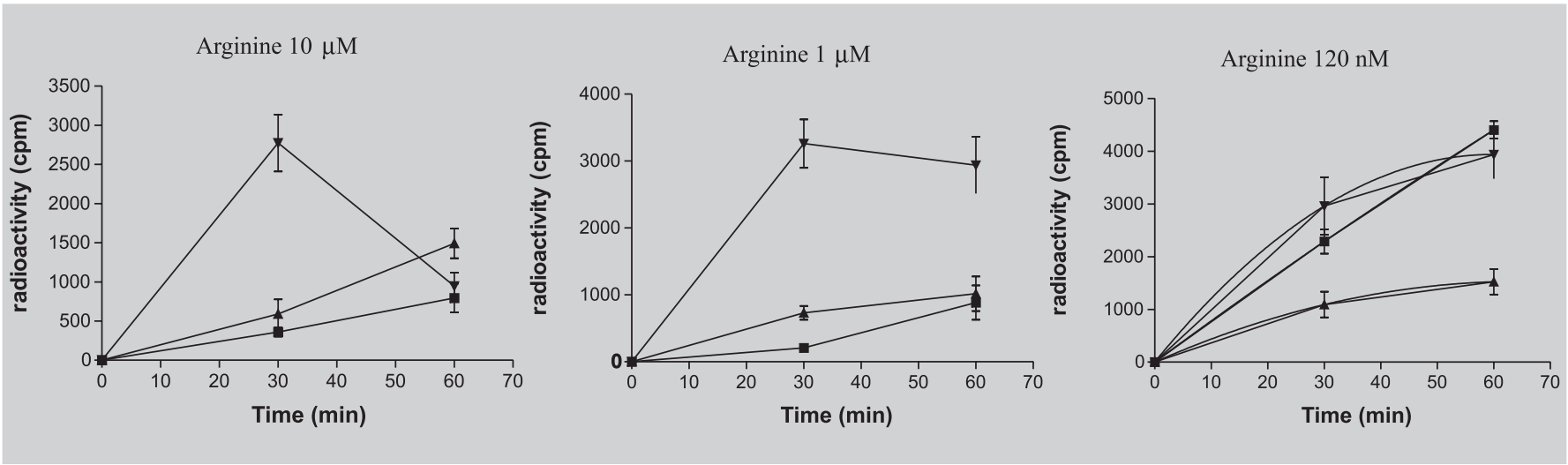

FIGURE 1 - Effect of arginine, protein concentration, and incubation time on NOS activity in a preparation from fresh human platelet. Three different L-arginine concentrations $(10 \mu \mathrm{M}, 1 \mu \mathrm{M}, 120 \mathrm{nM})$ were tested with different protein concentration $(40 \boldsymbol{\boldsymbol { }}, 80 \boldsymbol{\Delta}$ and $160 \mathrm{ug} \boldsymbol{\nabla})$ a fixed concentration of ${ }^{3} \mathrm{H}$-arginine $(0.5 \mu \mathrm{Ci})$ at 30 and 60 minutes of incubation. Results have been expressed as cpm, which was corrected for its own blank (homogenate omitted). Data consist of a representative experiment, which was repeated, and have been given as the mean of triplicate determination.

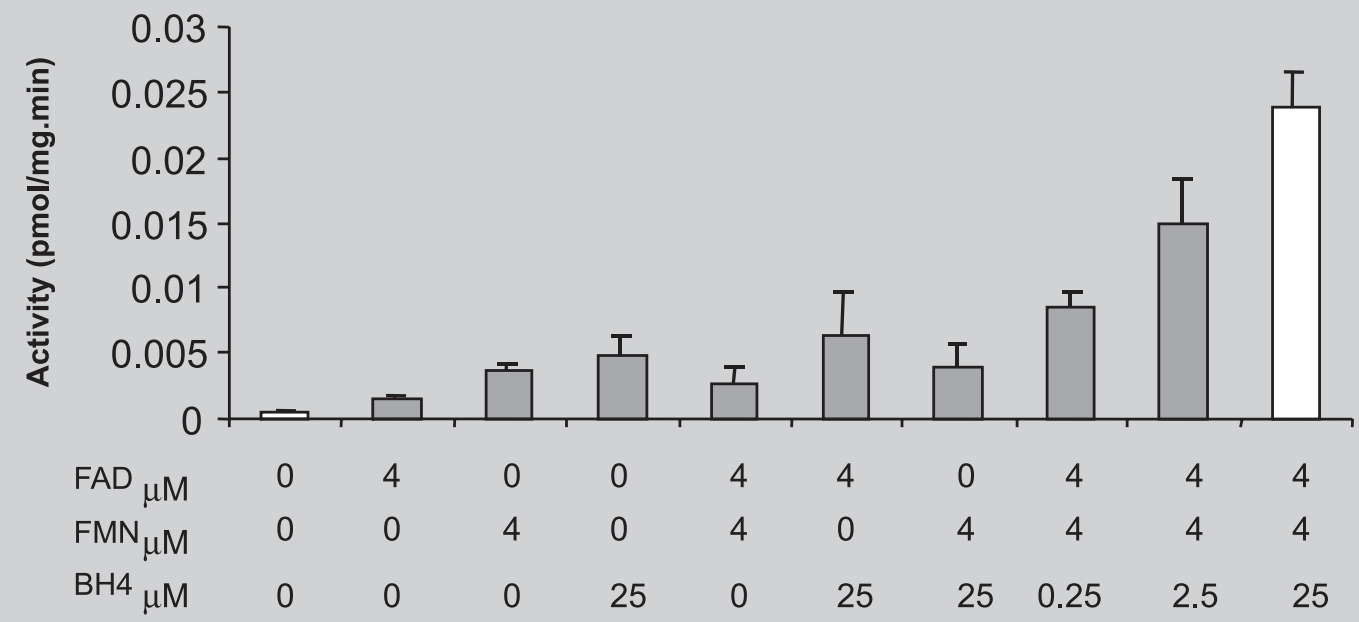

FIGURE 2 - Effects of the co-factors, FAD, $\mathrm{BH}_{4}$ and FMN, on NOS activity in human platelet. The clear bar represents control activity under standard conditions. Cofactors were investigated either singly (single hatching) or in combination (cross hatching). The concentration (M) used has been indicated under each bar. The composition of all the other components of the incubating medium was kept constant. Results were expressed as pmol. $\mathrm{mg}^{-1} \cdot \mathrm{min}^{-1}$ and have been given as the mean \pm SEM of 3-5 experiments each consisting of triplicate determination.

(approximately $2.8 \%$ ) was detected when none of the cofactors were added to the incubation medium. The addition of FAD, FMN or $\mathrm{BH}_{4}$ individually, enhances platelet NOS activity, but not to the level observed when they were present all together. The combination of two of the cofactors $\left(\mathrm{FAD}+\mathrm{FMN}, \mathrm{FAD}+\mathrm{BH}_{4}, \mathrm{FMN}+\mathrm{BH}_{4}\right)$ produced an increase on activity, but neither was able to reach the maximum enzyme activity. Therefore, the optimum activity was achieved using only all three $(4 \mu \mathrm{M}$ FAD, $4 \mu \mathrm{M}$ FMN, $25 \mu \mathrm{M} \mathrm{BH}_{4}$ ) cofactors.

\section{Inhibition of human NOS platelet by L-NAME}

L-NAME (10 $\mu \mathrm{M}$ and $1 \mathrm{mM})$, a inhibitor of the all isoforms of NOS was used to characterize the enzyme. LNAME $(10 \mu \mathrm{M})$ inhibited approximately $70 \%$ of platelet NOS and $1 \mathrm{mM}$ caused a complete inhibition of this enzyme activity (Figure 3 ). The total NOS activity can be expressed as the difference in activity in the presence and absence of L-NAME. 


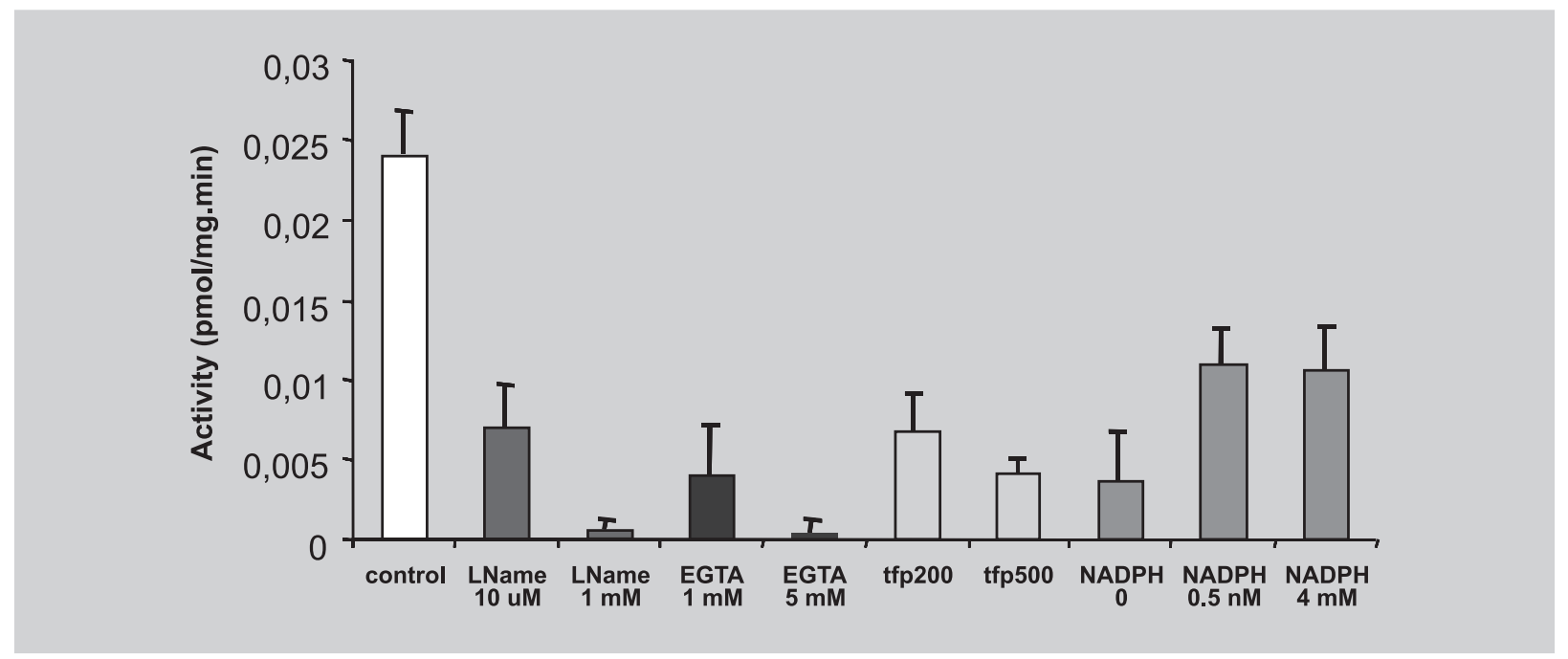

FIGURE 3 - Effects of the co-substrate, NADPH, and of the inhibitors, L-NAME, EGTA and TFP, on NOS activity in human platelet. The clear bar represents control activity measured under standard conditions. The incubation media were altered as indicated under each of the hatched bars. Results are expressed as pmol. $\mathrm{mg}^{-1} \cdot \mathrm{min}^{-1}$ and have been given as the mean \pm SEM of 3-5 experiments each consisting of triplicate determination.

$\mathrm{Ca}^{2+} /$ calmodulin dependence on platelet NOS activity

To further characterize human NOS platelet activity, it is important to test $\mathrm{Ca}^{2+}$-calmodulin dependence of this enzyme. To this purpose, a range of $\mathrm{Ca}^{2+}$ concentration was added to the incubation medium: $0,0.625,1.25$ (reference concentration) (Figure 4). In addition, EGTA was used as a calcium chelator $(1 \mathrm{mM}$ and $5 \mathrm{mM})$ and two different concentration (200 and $500 \mathrm{mM}$ ) of TFP were used to determine calmodulin dependence in NOS platelet (Figure 3)

EGTA caused $80 \%$ inhibition of NOS activity at $1 \mathrm{mM}$ and total inhibition at $5 \mathrm{mM}$ (Figure 5). The optimum concentration of NADPH was $1.0 \mathrm{mM}$ and of

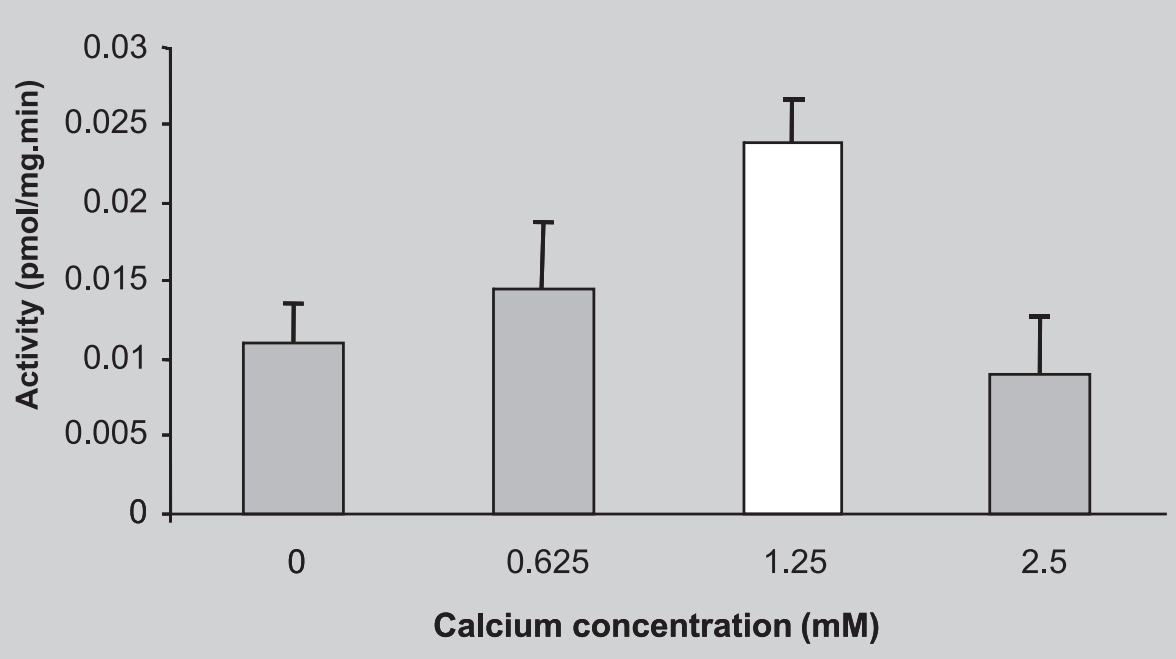

FIGURE 4 - Effects of $\mathrm{Ca}^{2+}$ concentration on NOS activity in human platelet. The clear bar represents control activity measured under standard conditions $\left(\mathrm{Ca}^{2+}\right.$ concentration, $\left.1.25 \mathrm{mM}\right) . \mathrm{Ca}^{2+}$ concentrations were altered as indicated under the hatched bars. Note that these concentrations represent those added exogenously and not the final concentration in the incubation medium which contains a non-specific chelator, EDTA. Results are expressed as pmol. $\mathrm{mg}^{-1}$. $\mathrm{min}^{-1}$ and have been given as the mean \pm SEM of 3-5 experiments each consisting of triplicate determination. 
$\mathrm{Ca}^{2+}$ was $1.25 \mathrm{mM}$ (Figure 3). Increases of NADPH concentration and $\mathrm{Ca}^{2+}$ induced a reduction of $140 \%$ and $60 \%$ of the NOS activity, respectively (Figure 3). TFP induced $73.2 \%$ inhibition of the enzyme activity at $200 \mathrm{mM}$ and $83.8 \%$ at $500 \mathrm{mM}$ (Figure. 3)

\section{DISCUSSION}

In the present study, an optimized NOS assay was characterized from a preparation of homogenate of human platelet. Preliminary results suggest that although eNOS activity in platelets is membrane-bound and is thus localized in the particulate fraction, we could detect NOS enzyme activity in platelet cytosol, as well as in homogenate of human platelets disrupted by sonication. The profile of higher NOS activity in human platelet homogenate when compared to either membrane or cytosol correlates well with results reported by Sase and Michel (1995), and suggests that this fraction should be used for studying the basic biochemical features of eNOS in platelet.

Evidences emerging from various laboratories shows that there are several different conditions in the assay of NOS activity in platelet, like different time of incubation, different concentrations of cofactors, NADPH, buffer, protein, L-arginine, $\left[{ }^{3} \mathrm{H}\right]$-arginine (Chen, Mehta, 1996; Mehta et al., 1995; Riddell et al., 1997; Sase, Michel, 1995). In addition, it has been reported that only large amount of whole blood (from $\sim 200 \mathrm{~mL}$ of whole blood) and protein $(\sim 10 \mathrm{mg} / \mathrm{mL})$ has to be used in order to obtain a good NOS activity in human platelet (Sase, Michel, 1995). However, the kinetic analysis of NOS activity by using different concentrations of the Larginine, and other requirements for eNOS activity has not been evaluated in human NOS platelet study. It is very important to establish that the concentration of arginine used is not rate limiting since it might be hard to demonstrate changes in the enzyme activity in experimental study where NOS activity increases (Lincoln, Messersmith, 1995). Our results confirm previous findings that the sensitivity of NOS assay on platelets is very low when compared with NOS activity on cerebellum (Sase, Michel, 1995; Mckee et al., 1994). Since the basis of the NOS assay is to measure the conversion of radioactive arginine to citrulline, the higher the levels of endogenous, non-radioactive arginine, the lower is the sensitivity of the assay. Therefore, it was necessary to remove endogenous arginine from crude supernatants by passing the sample through a Dowex ionexchange column. In addition, it was important to run control experiments in which NOS activity was measured after different incubation times and using different concentrations of tissue. Our experiments showed that the linear portion of the curve could be obtained with $80 \mu \mathrm{g}$ of protein at 30 and 60 minutes of incubation.

The kinetic analysis of platelet NOS activity was based on Garvey et al. (1994) and Wolf et al. (1994) by using three different $\mathrm{L}$-arginine concentrations with a fixed concentration of ${ }^{3} \mathrm{H}$-arginine $(0.5 \mu \mathrm{Ci})$. In order to have high enough arginine concentration in the assay, ${ }^{3} \mathrm{H}-$ arginine can be mixed with non-radioactive arginine. Thus, it was necessary to determine the relative proportions of radioactive and non-radioactive arginine in the working solution so that the change in specific activity of ${ }^{3} \mathrm{H}$-arginine can be calculated. Experiments in platelets using 1 and $10 \mathrm{mM}$ concentration of L-arginine have obtained high NOS activity but there is a reduction in specific activity, which reduce the sensitivity of the assay. In addition, the dose-response curve was not linear when high concentrations of arginine were used in NOS assay. Thus, the working solution with the best specific activity was obtained in the presence of $120 \mathrm{nM}$ of L-arginine with a fixed concentration of ${ }^{3} \mathrm{H}$-arginine $(0.5 \mu \mathrm{Ci})$. Under basal conditions, NOS Km for L-arginine was $0.84 \pm$ $0.08 \mu \mathrm{M}$ and mean $\mathrm{Vmax}$ values were $0.122 \pm$ $0.025 \mathrm{pmol} \cdot \mathrm{mg}^{-1} \cdot \mathrm{min}^{-1}$. Mean human NOS platelet activity was $0.020 \pm 0.010 \mathrm{pmol} . \mathrm{mg}^{-1} \cdot \mathrm{min}^{-1}$.

The dependence of the presence of co-substrate and cofactors in NOS activity have been reported in different tissue preparation, such as kidney, myenteric plexus, dorsal brain stem, neutrophils, dorsal periaquedutal gray, spinal cord and LLC-PK 1 cells (Lincoln, Messersmith, 1995; Mckee et al., 1994; Barjavel, Bhargava, 1995; Pontieri et al., 1998; Cerchiaro et al., 2001; Chiavegatto et al., 1998). Our results also demonstrated a dependence of the presence of co-factor when measuring NOS activity in platelet homogenate. However, previous studies have reported that FMN concentrations had little effect when compared to FAD and BH4 in NOS activity in crude cytosolic preparation (Lincoln, Messersmith, 1995). The present data showed that in platelet, all three co-factors had to be added for maximal activity to occur, and the absence of any of them induced an important decrease in NOS activity. In fact, NOS activity in the absence of FAD, FMN and $\mathrm{BH}_{4}$ was only $2.8 \%$ of the activity measured in the presence of these three cofactors. The intracellular concentration of FAD $(4 \mu \mathrm{M})$ and FMN $(4 \mu \mathrm{M})$ required to maximal activity in platelet was similar to that reported to other tissues (Mckee et al., 1994, Sase, Michel, 1995). However, the intracellular concentration of $\mathrm{BH}_{4}$ under normal physiological conditions in platelet is not established. Thus, we used a range of intracellular 
concentration of $\mathrm{BH}_{4}$ from 0.25 to $25 \mu \mathrm{M}$ and the maximal activity was achieved with $25 \mu \mathrm{M}$.

The enzyme activity was completely inhibited by L-NAME (1 mM) (98.1\%) and EGTA (5 mM) (98.8\%). The results also showed that human platelet NOS activity is highly dependent on NADPH and $\mathrm{Ca}^{2+}$ in the incubation medium since the absence of both induced a tremendous decrease in the enzyme activity. Interestingly, the increase of $\mathrm{Ca}^{2+}$ concentration above $1.25 \mathrm{mM}$ resulted in inhibition of NOS activity. It should be noted that $\mathrm{Ca}^{2+}$ concentration added in the medium does not represent the final free $\mathrm{Ca}^{2+}$ concentration since the non-specific divalent cation chelator EDTA is present in the homogenizing buffer. It should be noted that the omission of calmodulin from the incubating media was not sufficient to induce any decrease in the enzyme activity (data not shown) probably due to the binding of this compound to the enzyme during tissue preparation as it has been suggested to iNOS (Cho et al., 1992). However, TFP, a calmodulin antagonist, caused $73.2 \%$ inhibition of the enzyme activity at $200 \mu \mathrm{M}$ and $83.8 \%$ at $500 \mu \mathrm{M}$.

Therefore, the present studies indicate that NOS activity in human platelet are highly dependent on the appropriate substrate and $\mathrm{Ca}^{2+}$ concentration, as well as on exogenous co-fators for maximal activity. Given the extensive involvement of NOS in disease states, the procedure described here should be able to provide good indications of NOS activity in human platelet when investigating changes in the enzyme activity in pathological conditions.

\section{ACKNOWLEDGMENTS}

This work was supported by research grants from Fundação de Amparo à Pesquisa do Estado de São PauloFAPESP and Bunka Fund - Sumitomo Bank for E.M.K, I.G., E.M.K. and C.D.M. are supported by student research fellowship from FAPESP and C.S.B. is supported by University of São Paulo (Projeto IV). C.S. are research fellow of Conselho Nacional de Desenvolvimento Científico e Tecnológico.

\section{RESUMO}

\section{Atividade da Óxido Nítrico Sintase em plaquetas hu- manas: um método otimizado}

A análise cinética da atividade da óxido nitrico sintase (NOS) plaquetária foi avaliada pela conversão de $\left[{ }^{3} \mathrm{H}\right]$-arginina em $\left[{ }^{3} \mathrm{H}\right]$-citrulina em plaquetas humanas frescas não estimuladas. A atividade da NOS foi detectada na fração citosólica e na membrana, além de ser dependente de $\mathrm{Ca}^{2+}$-calmodulina, que é uma característica da NOS endotelial (eNOS). A omissão de NADPH levou à diminuição da atividade da NOS dependente da dose causando redução de $85,2 \%$ da atividade enzimática. A cinética variou de acordo com as concentrações de proteina e de arginina, sendo que as melhores leituras foram obtidas com $80 \mu \mathrm{g}$ de proteina, $120 \mathrm{nM}$ de arginina em $0,5 \mu \mathrm{Ci}$ de ${ }^{3} \mathrm{H}$ arginina, em 60 minutos de incubação. A atividade da NOS na ausência de FAD (flavina adenina dinucleotídeo), FMN (flavina mononucleotídeo) e $\mathrm{BH}_{4}$ (tetrahidrobiopterina) foi de apenas 2,8\% da atividade medida na presença destes três cofatores. A atividade da enzima foi completamente inibida pelo L-NAME (1 mM; 98,1\%), EGTA (5 mM; 98,8\%) e adição de trifluoperazina (TFP), nas concentrações de $200 \mu \mathrm{M}$ e $500 \mu \mathrm{M}$, inibiu a atividade da enzima em 73,2\% e 83,8\%, respectivamente. Em condições basais, o Km da NOS para Larginina foi de 0,84 $\pm 0,08 \mu M$ e o valor de Vmax foi de $0,122 \pm 0,025 \mathrm{pmol} \cdot \mathrm{mg}^{-1} \cdot \mathrm{min}^{-1}$. A atividade média da NOS plaquetária humana foi de 0,020 $\pm 0,010$ pmol.mg-1. $\mathrm{min}^{-1}$. Os resultados indicam que a eNOS em plaquetas humanas pode ser avaliada pelo método da conversão de $\left[{ }^{3} \mathrm{H}\right]$-arginina em $\left[{ }^{3} \mathrm{H}\right]$-citrulina, que em condições otimizadas, fornece resultados reprodutiveis e precisos com ótima sensibilidade para experimentos clínicos envolvendo doenças neurológicas e psiquiátricas.

UNITERMOS: NOS. Plaquetas. Humano. Arginina. Citrulina.

\section{REFERENCES}

AISAKA, K., GROSS, S. S., GRIFFITH, O. W., LEVI, R. $\mathrm{N}^{\gamma}$-methylarginine, an inhibitor of endothelium derives nitric oxide synthesis, is a potent pressor agent in the guinea-pig: does nitric oxide synthesis regulate blood pressure in vivo ? Biochem. Biophys. Res. Commun., v. 160, p. 881-886, 1989.

BARJAVEL, M. J., BHARGAVA, H. N. Nitric oxide synthase activity in brain regions and spinal cord of mice and rats: kinetic analysis. Pharmacology, v. 50, p. 168 174, 1995.

BERKELS, R., STOCKKLAUSER, K., ROSEN, P., ROSEN, R. Current status of platelet NO synthases. Thromb. Res., v. 87, p. 51-55, 1997. 
BRADFORD, M. M. A rapid and sensitive methods for the quantification of microgram quantities of protein utilizing the principle of protein-dye binding. Anal. Biochem., v. 72, p. 278, 1976.

BREDT, D. S., SNYDER, S. H. Isolation of nitric oxide synthase, a calmodulin-requiring enzyme. Proc. Natl. Acad. Sci. USA, v. 87, p. 682-685, 1990.

CAMACHO, A., DIMSDALE, J. E. Platelets and psychiatry: lessons learned from old and new studies. Psychosomatic Med., v. 62, p. 326-336, 2000.

CERCHIARO, G. A., SCAVONE, C., TEIXEIRA, S., SANNOMIYA, P. Inducible nitric oxide synthase in rat polymorphonuclear leukocytes: role of insulin. Biochem. Pharmacol., v. 62, p. 357-362, 2001.

CHEN, L. Y., MEHTA, J. L. Variable effects of L-arginine analogs on L-arginine- nitric oxide pathway in human neutrophils and platelets may relate to different nitric oxide synthase idoforms. J. Pharmacol. Exp. Ther., v. 276, p. 253-257, 1996.

CHIAVEGATTO, S., SCAVONE, C., CANTERAS, N. S. Nitric oxide synthase activity in the dorsal periaqueductal gray of rats expressing innate fear response. NeuroReport, v. 9, p. 571-576, 1998.

CHO, H. J., XIE, Q. W., CALAYCAY, J., MUMFORD, R. A., SWIDEREK, K. M., LEE, T. D., NATHAN, C. Calmodulin is a subunit of nitric oxide synthase from macrophages. J. Exp. Med., v. 176, p. 599-604, 1992.

CONRAD, K. P., DAVIS, A. K. Nitric oxide synthase activity in placentae from women with pre-eclampsia. Placenta, v. 16, p. 691-699, 1995.

GARTHWAITE, J., BOULTON, C. L. Nitric oxide signaling in the central nervous system. Ann. Rev. Physiol., v. 57, p. 683-706, 1995.

GARVEY, P., TUtTle, J. V., COVington, K., MERRILL, B. M., WOOD, E. R., BAYLIS, S. A., CHARLES, I. G. Purification and characterization of the constitutive nitric oxide synthase from human placenta. Arch. Biochem. Biophys., v. 311, p. 235-241, 1994.
GASPARINI, L., RACCHI, M., BINETTI, C., TRABUCCHI, M., SOLERTE, S. B., ALKON, D., ETCHEBERRIGARAY, R., GIBSON, G., PAOLETTI, R., GOVONI, S. Peripheral markers in testing pathophysiological hypothesis and diagnosing Alzheimer's disease. FASEB J.,v. 12, p. 17-34, 1998.

HIBBS, J. B., TAINTOR, R. R., VAVRIN, Z., GRANGER, D. L., DRAPIER, J. C., AMBER, I. J., LANCASTER, J. $R$. Synthesis of nitric oxide from a terminal guanidino atom of L-arginine: a molecular mechanism regulating cellular proliferation that targets intracellular iron. In: MONCADA, S., HIGGS, E. A., eds. Nitric oxide from Larginine: a bioregulatory system. Amsterdam: Elsevier, 1990. p. 189-223.

HEVEL, J. M., MARLETTA, M. A. Nitric-oxide synthase assays. Methods Enzymol., v. 233, p. 250-258, 1994.

HOURANI, S. M., CUSACK, N. J. Pharmacological receptors on blood platelets. Pharmacol. Rev., v. 43, p. 243-298, 1991.

LANTOINE, F., BRUNET, A., BEDIOUI, F., DEVYNCK, J., DEVYNCK, M. A. Direct measurement of nitric oxide production in platelets: relationship with cytosolic $\mathrm{Ca}^{2+}$ concentration. Biochem. Biophys. Res. Commun., v. 215, p. 842-848, 1995.

LINCOLN, J., MESSERSMITH, W. A. Conditions required for the measurement of nitric oxide synthase activity in a myenteric plexus/ smooth muscle preparation from the rat ileum. J. Neurosci. Methods, v. 59, p. 191-197,1995.

MALINSKI, T., RADOMSKI, M. W., TAHA, Z., MONCADA, S. Direct eletrochemical measurement of nitric oxide released from human platelets. Biochem. Biophys. Res. Commun., v. 194, p. 960-965, 1993.

MCKEE, M., SCAVONE, C., NATHANSON, J. A. Nitric oxide, cGMP, and hormone regulation of active sodium transport. Proc. Natl. Acad. Sci., v. 91, p. 12056-12060, 1994.

MEHTA, J. L., CHEN, L. Y., MEHTA, K. P., TURNER, P. Identification of constitutive and inducible forms of nitric oxide synthase in human platelets. J. Lab. Clin. Med., v. 125, p. 370-377, 1995. 
MILES, A. M., BOHLE, D. S., GLASSBRENNER, B., HANSERT, D. A., WINK, G., GRISHAM, M. B. Modulation of superoxide-dependent oxidation and hydroxylation reactions by nitric oxide. J. Biol. Chem., v. 271, p. 40-47, 1996.

MURUGANANDAM, A., MUTUS, B. Isolation of nitric oxide synthase from human platelets. Biochim. Biophys. Acta, v. 1200, p. 1-6, 1994.

PLETSCHER, A., SHORE, P. A., BRODIE, B. B. Serotonin as a mediator of reserpine action in brain. J. Pharmacol. Exp. Ther., v. 116, p. 84-89, 1956.

PLETSCHER, A. Platelets as models: use and limitations. Experientia, v. 44, p. 152-155, 1988.

PONTIERI, V., VENEZUELA, M. K., SCAVONE, C., MICHELINI, L. C. Role of endogenous nitric oxide in the nucleus tractus solitarii on baroreflex control of heart rate in spontaneously hypertensive rats. J. Hypertens., v. 16, p. 1993-1999, 1998.

RADOMSKI, M. W., PALMER, R. M. J., MONCADA, S. Characterization of the L-arginine: nitric oxide pathway in human platelets. Brit. J. Pharmacol., v.101, p. 325328,1990a.
RADOMSKI, M. W., PALMER, R. M. J., MONCADA, S. An L-arginine/ nitric oxide pathway present in human platelets regulates aggregation. Proc. Natl. Acad. Sci., v.87, p. 5193-5197, $1990 \mathrm{~b}$.

REES, D. D., PALMER, R. M. J., HODSON, H. F., MONCADA, S. A specific inhibitor of nitric oxide formation from L-arginine attenuates endothelium dependent relaxation. Brit. J. Pharmacol., v. 96, p. 418424, 1989.

RIDDELL, D. R., GRAHAM, A., OWEN, J. S. Apolipoprotein E inhibits platelet aggregation through the L-arginine:nitric oxide pathway. J. Biol. Chem., v. 272, p 89-95, 1997.

SASE, K., MICHEL, T. Expression of constitutive endothelial nitric oxide synthase in human blood platelets. Life Sci., v. 57, p. 2049-2055, 1995.

WOLF, D. J., LUBESKIE, A., UMANSKY, S. The inhibition of the constitutive bovine endothelial nitric oxide synthase by imidazole and indazole agents. Arch. Biochem. Biophys., v. 314, p. 360-366, 1994.

Recebido para publicação em 09 de agosto de 2002. 